NBER WORKING PAPER SERIES

HOW BIG (SMALL?) ARE FISCAL MULTIPLIERS?

\author{
Ethan Ilzetzki \\ Enrique G. Mendoza \\ Carlos A. Végh \\ Working Paper 16479 \\ http://www.nber.org/papers/w16479 \\ NATIONAL BUREAU OF ECONOMIC RESEARCH \\ 1050 Massachusetts Avenue \\ Cambridge, MA 02138 \\ October 2010
}

We thank Giancarlo Corsetti, Antoinio Fatas, James Feyrer, Yuriy Gorodnichenko, Guy Michaels, Phillip Lane, Roberto Perotti, Carmen Reinhart, Vincent Reinhart, Luis Serven, Todd Walker, Tomasz Wieladek and participants at several conferences and seminars for their useful comments. We thank numerous officials at ...nance ministries, central banks, national statistical agencies, and the IMF for their assistance in compiling the dataset. Giagkos Alexopoulos, Florian Blum and Daniel Osorio-Rodriguez provided excellent research assistance. The views expressed herein are those of the authors and do not necessarily reflect the views of the National Bureau of Economic Research.

NBER working papers are circulated for discussion and comment purposes. They have not been peerreviewed or been subject to the review by the NBER Board of Directors that accompanies official NBER publications.

(C) 2010 by Ethan Ilzetzki, Enrique G. Mendoza, and Carlos A. Végh. All rights reserved. Short sections of text, not to exceed two paragraphs, may be quoted without explicit permission provided that full credit, including $(\mathcal{C}$ notice, is given to the source. 
How Big (Small?) are Fiscal Multipliers?

Ethan Ilzetzki, Enrique G. Mendoza, and Carlos A. Végh

NBER Working Paper No. 16479

October 2010, Revised September 2012

JEL No. E2,E6,F41,H5

\begin{abstract}
$\underline{\text { ABSTRACT }}$
We contribute to the debate on the macroeconomic effects of fiscal stimuli by showing that the impact of government expenditure shocks depends crucially on key country characteristics, such as the level of development, exchange rate regime, openness to trade, and public indebtedness. Based on a novel quarterly dataset of government expenditure in 44 countries, we find that (i) the output effect of an increase in government consumption is larger in industrial than in developing countries, (ii) the fiscal multiplier is relatively large in economies operating under predetermined exchange rates but is zero in economies operating under flexible exchange rates; (iii) fiscal multipliers in open economies are smaller than in closed economies; (iv) fiscal multipliers in high-debt countries are negative.

Ethan Ilzetzki

London School of Economics

Houghton Street

London WC2A 2AE

e.ilzetzki@LSE.ac.uk

Enrique G. Mendoza

Department of Economics

University of Maryland

College Park, MD 20742

and NBER

mendozae@econ.umd.edu

Carlos A. Végh

Department of Economics

Tydings Hall, Office $4118 \mathrm{G}$

University of Maryland

College Park, MD 20742-7211

and NBER

vegh@econ.bsos.umd.edu
\end{abstract}




\title{
How Big (Small?) are Fiscal Multipliers?
}

\author{
Ethan Ilzetzki* \\ Enrique G. Mendoza \\ London School of Economics \\ University of Maryland and NBER \\ Carlos A. Végh \\ University of Maryland and NBER
}

This Draft: March 22, $2012^{\dagger}$

\begin{abstract}
We contribute to the debate on the macroeconomic effects of fiscal stimuli by showing that the impact of government expenditure shocks depends crucially on key country characteristics, such as the level of development, exchange rate regime, openness to trade, and public indebtedness. Based on a novel quarterly dataset of government expenditure in 44 countries, we find that (i) the output effect of an increase in government consumption is larger in industrial than in developing countries, (ii) the fiscal multiplier is relatively large in economies operating under predetermined exchange rates but is zero in economies operating under flexible exchange rates; (iii) fiscal multipliers in open economies are smaller than in closed economies; (iv) fiscal multipliers in high-debt countries are negative.
\end{abstract}

As fiscal stimulus packages were hastily put together around the world in early 2009, one could not have been blamed for thinking that there must be some broad agreement

\footnotetext{
${ }^{*}$ Corresponding author. London School of Economics, Houghton Street, London WC2 2AE, United Kingdom. Tel: +44-20-7955-7510 Email: e.ilzetzki@lse.ac.uk.

${ }^{\dagger}$ We thank Giancarlo Corsetti, Antoinio Fatas, James Feyrer, Yuriy Gorodnichenko, Guy Michaels, Phillip Lane, Roberto Perotti, Carmen Reinhart, Vincent Reinhart, Luis Serven, Todd Walker, Tomasz Wieladek and participants at several conferences and seminars for their useful comments. We thank numerous officials at finance ministries, central banks, national statistical agencies, and the IMF for their assistance in compiling the dataset. Giagkos Alexopoulos, Florian Blum and Daniel Osorio-Rodriguez provided excellent research assistance.
} 
in the profession regarding the size of the fiscal multipliers. Far from it. In a January 2009 Wall Street Journal op-ed piece, Robert Barro argued that peacetime fiscal multipliers were essentially zero. At the other extreme, Christina Romer, Chair of President Obama's Council of Economic Advisers at the time, used multipliers as high as 1.6 in estimating the job gains that would be generated by the $\$ 787$ billion stimulus package approved by Congress in February 2009. The difference between Romer's and Barro's views of the world amounts to a staggering 3.7 million jobs by the end of 2010. If anything, the uncertainty regarding the size of fiscal multipliers in developing and emerging markets is even greater. Data are more scarce and often of dubious quality. A history of fiscal profligacy and spotty debt repayments calls into question the sustainability of any fiscal expansion.

How does financial fragility affect the size of fiscal multipliers? Does the exchange regime matter? What about the degree of openness? There is currently little empirical evidence to shed light on these critical policy questions. This paper aims to fill this gap by conducting a detailed empirical analysis that establishes the relevance of key country characteristics in predicting whether and when fiscal stimulus is effective or ineffective.

A big hurdle in obtaining precise estimates of fiscal multipliers has been data availability. Most studies have relied on annual data, which makes it difficult to obtain precise estimates. To address this shortcoming, we have put together a novel quarterly dataset for 44 countries (20 high-income and 24 developing). The coverage, which varies across countries, spans from as early as 1960:1 to as late as 2007:4. We have gone to great lengths to ensure that only data originally collected on a quarterly basis is included (as opposed to interpolated from annual data). Using this unique database-and sorting countries based on various key characteristics-we estimate fiscal multipliers for different groups of countries and episodes in our sample. The paper's main results can be summarized as follows:

1. The degree of development is a critical determinant of the size of the fiscal multipliers. We find that, in developing countries, the response of output to increases in government consumption is negative on impact (and not statistically significantly different from zero). In contrast, the response of output in industrial countries is positive on impact (and significantly different from zero). Further, in developing countries, the cumulative response of output is negative and not statistically different from zero. In contrast, the positive output effect in industrial countries is highly persistent and statistically 
significant from zero in the long run. Fiscal policy differs in developing countries not only in its effect, but also in its execution, as increases in government consumption are far more transient (dying out after approximately 6 quarters), in contrast to highly persistent government consumption shocks in high-income countries.

2. The degree of exchange rate flexibility is a also critical determinant of the size of fiscal multipliers. Economies operating under predetermined exchange rate regimes have long-run multipliers that are larger than one, but economies with flexible exchange rate regimes have negative multipliers both on impact and the long run. The fiscal multiplier in countries with predetermined exchange rates is statistically different from zero and from the multiplier in countries with flexible exchange arrangements at any forecast horizon. We find that the main difference between the response to government consumption in countries with different exchange rate regimes is in the degree of monetary accommodation to fiscal shocks. Our evidence supports the notion that the response of central banks to fiscal shocks is crucial in assessing the size of fiscal multipliers.

3. Openness to trade is another critical determinant. Economies that are relatively closed (whether due to trade barriers or larger internal markets) have long-run multipliers of around 1 , but relatively open economies have negative multipliers. The difference in fiscal multiplier across these two groups is statistically significant for the first five years. In economies with small proportions of trade to GDP the multiplier is statistically different from zero in both the short and long run.

4. During episodes where the outstanding debt of the central government was high (exceeding 60 percent of GDP), the fiscal multiplier was not statistically different from zero on impact and was negative (and statistically different from zero) in the long run. Experimentation with a range of sovereign debt ratios indicated that the 60 percent of GDP threshold, used for example by the Eurozone as part of the Maastricht criteria, is indeed a critical value above which fiscal stimulus may have a negative impact on output in the long run.

5. We find that the multiplier on government investment in developing countries is positive, larger than one in the long run, and statistically different from the multiplier on 
government consumption at forecast horizons of up to two years. This indicates that the composition of expenditure may play an important role in assessing the effect of fiscal stimulus in developing countries. Our point estimate of the fiscal multiplier on government investment is larger than that of government consumption in high-income countries and other country groupings as well, but this difference is small and not statistically significant.

Given increasing trade integration and the adoption of flexible exchange rate arrangementsparticularly the adoption of inflation targeting regimes-our results cast doubt on the effectiveness of fiscal stimuli. Moreover, fiscal stimuli may even become even weaker, and potentially yield negative multipliers in the near future, because a large number of countries are now carrying very high public debt ratios. Moreover, our results provide new evidence on the importance of fiscal-monetary interactions as a crucial determinant of the effects of fiscal policy on GDP.

The paper proceeds as follows: Section 1 discusses the empirical methodology and puts our paper in the context of the existing literature. Section 2 describes the new dataset used in this study. Section 3 presents the econometric analysis and reports the results. Section 4 concludes.

\section{Methodology and Contribution}

A central issue in the ongoing debate on fiscal multipliers is that there is substantial disagreement in the profession regarding how one should go about identifying fiscal shocks. This identification problem arises because there are two possible directions of causation: (i) government spending could affect output or (ii) output could affect government spending (through, e.g., automatic stabilizers and implicit or explicit policy rules).

Two main approaches have been used to address this identification problem: (i) the structural vector autoregression approach (SVAR), first used for the study of fiscal policy by Blanchard and Perotti (2002) and (ii) the "natural experiment" of large military buildups in the United States first suggested by Barro (1981) and further developed by Ramey and Shapiro (1998).

In this paper, we employ the SVAR approach as in Blanchard and Perotti (2002). In our 
case the choice is forced because the military buildup approach has so far been applied only the US and is not practical for a large panel of countries. The validity of military expenditure as an instrument for public spending hinges on two assumptions. First, military expenditure and war efforts must be driven by global geopolitical factors and not domestic economic conditions. Second, these wars must have had no impact on macroeconomic outcomes except through the increases in public spending they induced. But while US wars have been fought primarily on foreign soil and have not involved significant direct losses of productive capital, this is certainly not the case in developing or smaller developed countries. Identifying government consumption through military purchases would risk conflating the effects of government consumption on output with those of war, risking significant mis-estimation of fiscal multipliers in these countries.

The basic assumption behind the SVAR approach used in this paper is that fiscal policy requires some time to respond to news about the state of the economy. After using a VAR to eliminate predictable responses of endogenous variables, it is assumed that any remaining correlation between the residual (unpredicted) components of government spending and output is due to the impact of government spending on output.

We wish to highlight the importance of high-frequency data for the validity of this identification scheme. As Blanchard and Perotti (2002), who pioneered this approach, pointed out: "We use quarterly data because, as we discuss below, this is essential for identification of the fiscal shocks." (p. 1332). While it is reasonable to assume that fiscal authorities require a quarter to respond to output shocks, it is unrealistic to assume that an entire year is necessary. For example, many countries, including developing countries, responded with discretionary measures as early as the first quarter of 2009 to the economic fallout following the collapse of Lehman Brothers and AIG, at the end of the third quarter of 2008. While, in this particular instance, the shock and response occurred in different calendar years, it suggests it is not generally valid to assume that governments require an entire year to respond to the state of the economy.

A notable contribution of our paper, therefore, is in cataloguing quarterly data on government expenditure for a large sample of countries, including developing countries. We outline the details of our new dataset in the following section. To our knowledge, all previous research on the effects of fiscal policy on output using international data (e.g. Beetsma et al, 2008 and Corsetti et al, 2011) have relied on lower frequency data. 
In particular, this is the first study to use quarterly-frequency data from, and provide estimates for, developing countries. As we point out below, recent improvements in data quality in a number of developing countries have made working with quarterly data possible. Inclusion of developing countries may also aid in the identification of fiscal shocks.

One critique of the SVAR approach is that fiscal shocks identified using an SVAR were predicted by the private sector although they are unpredictable by the econometrician (see Ramey, 2011, for example). In Appendix A.1, we provide some suggestive evidence that this is not the case in developing countries. We show that even central banks in developing countries had little ability to estimate government expenditure in real time and that their data revisions are correlated with SVAR residuals. This indicates that their information set on high-frequency movements in government expenditures was similar to that of the econometrician. Overall, fiscal policy in developing countries is sufficiently volatile-even within the course of a fiscal year-that it is unlikely that private agents had good real-time estimates of fiscal shocks.

Broad surveys of the literature estimating the fiscal multiplier are provided in Ramey (2011b) and Parker (2011). Here we highlight work that has used a similar methodology to the one we employ. In the few OECD countries that have been studied so far, the existing range of estimates in the SVAR literature varies considerably. Specifically, Blanchard and Perotti (2002) find a multiplier of close to 1 in the United States for government purchases. Perotti (2004a, 2007), however, shows that estimates vary greatly across (five OECD) countries and across time, with a range of -2.3 to 3.7. Other estimates for the United States-using variations of the standard SVAR identifying assumption-yield values of 0.65 on impact but -1 in the long run (Mountford and Uhlig, 2009) and larger than one (Fatas and Mihov, 2001).

Given the range of fiscal multiplier estimates, it is natural to ask what determines where and when fiscal policy has had a greater impact. The short sample of macroeconomic data makes this a difficult question to answer for an individual country and recent studies have turned to panels of international data in attempt to shed light on this question. ${ }^{1}$ Beetsma et al (2008) estimate the fiscal multiplier for EU countries in a Panel VAR and find a peak multiplier of 1.6. However, they use annual data to obtain this estimate, and the main focus of their paper is the response of the trade balance to fiscal shocks. Similar to our

\footnotetext{
${ }^{1}$ There is also a growing literature using cross-sectional or panel data of US States. See for example Nakamura and Steinsson (2011) and Wilson (2012).
} 
results regarding the importance of exchange rate regimes and highly-indebted countries, Corsetti et al (2011) show in a panel of industrialized countries that fiscal multipliers are larger under fixed than under flexible exchange rates, lower when debt is high (greater than $100 \%$ of GDP), and larger during financial crises. However, their dataset is annual and they use the identification method of Perotti (1999) rather than the SVAR approach. Auerbach and Gorodnichenko $(2011,2012)$ use structural VARs for the US and a panel of high-income countries to compare the effects of fiscal policy in expansion and recession. They find that fiscal multipliers are larger in recessions than in expansions. ${ }^{2}$ Their panel data, however, is semi-annual.

Our paper also explores how the magnitude of fiscal multipliers depends on the economic context. We provide estimates using quarterly data for a broad panel of countries, including developing countries. Our larger sample allows more accurate estimates of the fiscal multiplier and more robust evidence on the differences in fiscal multipliers across countries. We introduce quarterly data-important for the credibility of the SVAR identifying assumption-in an international panel estimate of fiscal multipliers. Our paper also introduces high-frequency fiscal data for developing countries.

\section{Data}

To the best of our knowledge, this paper involves the first attempt to catalogue quarterly data on government consumption in a broad set of countries. Until recently, only a handful of countries (Australia, Canada, the U.K. and the U.S.) collected government expenditure data at quarterly frequency and classified data into functional categories such as government consumption and government investment.

The use of quarterly data that is collected at a quarterly frequency is essential for the validity of the identifying assumptions used in an SVAR. SVAR analysis assumes that fiscal authorities require at least one period to respond to new economic data with discretionary policy. As noted above, we believe that the use of quarterly data is crucial in order to maintain the identifying assumption that fiscal authorities require one period to respond to output shocks.

\footnotetext{
${ }^{2}$ In an earlier version of this paper, we obtained similar results in our sample.
} 
In addition, data reported at a quarterly frequency but collected at annual frequency may lead to spurious regression results. Many standard datasets provide data that was reported at quarterly frequency, but was interpolated from annual data. For example, a series for quarterly (general) government consumption expenditure can be readily obtained from the International Monetary Fund's (IMF) International Finance Statistics database (series 27391F.CZF). However, a look at Mexico's country page on the IMF's Special Data Dissemination Standard (SDDS) website shows that "annual calculations provide the levels of GDP by production and by expenditure category, which are extrapolated by appropriate indices to obtain quarterly values" ${ }^{3}$. The quality of high frequency data on government consumption reported in standard sources cannot be taken for granted.

There are significant pitfalls stemming from the use of interpolated data for empirical analysis. One common method of interpolating government expenditure data that was collected at annual frequency is to use the quarterly seasonal pattern of revenue collection as a proxy for the quarterly seasonal pattern of government expenditure (data on tax revenues are more commonly collected at quarterly frequency). ${ }^{4}$ As tax revenues are highly procyclical, this method of interpolation creates a strong correlation between government expenditure and output by construction. Using an SVAR to identify fiscal shocks with data constructed in such a manner would clearly yield economically meaningless results.

The new dataset used in this paper exploits the fact that a larger number of countries have begun to collect fiscal data at a quarterly frequency. Two recent changes have made high-frequency fiscal data available for a broader set of countries. First, the adoption in 1996 of a common statistical standard in the European Monetary Union, the ESA95, encouraged European countries to collect and classify fiscal data at quarterly frequency. ${ }^{5}$ In its 2006 Manual on Non-Financial Accounts for General Government, Eurostat reports that all Eurozone countries comply with the ESA95, with quarterly data based on direct information available from basic sources that represent at least 90 percent of the amount in each expenditure category. ${ }^{6}$

Second, the IMF adopted the SDDS in 1996. Subscribers to this standard are required to collect and report central government expenditure data at annual frequency, with quar-

\footnotetext{
${ }^{3} \mathrm{http}: / /$ dsbb.imf.org/Pages/SDDS/CtyCtgBaseList.aspx?ctycode=MEX\&catcode=NAG00

${ }^{4}$ We have learned this from personal conversations with officials at numerous national statistical agencies.

${ }^{5}$ See http://circa.europa.eu/irc/dsis/nfaccount/info/data/ESA95/en/een00000.htm for more details.

${ }^{6}$ Austria was an exception with a coverage of $89.6 \%$ and is not included in our sample.
} 
terly frequency recommended. A number of SDDS subscribers have since been collecting fiscal data at quarterly and even monthly frequency and classifying expenditure data into functional categories at high frequencies.

For several countries, these improved data standards translated into reliable quarterly data on government consumption and investment in commonly used data sources. For example, quarterly data on these series are available via the Eurostat database for many EU countries, starting 1999 or earlier. For many other countries, notably developing countries, additional work was required. To illustrate how we arrived at quarterly series for government expenditure categories where these were unavailable elsewhere, we return to the example of Mexico. As mentioned earlier, the quarterly government consumption data in Mexico's national accounts are interpolated from annual frequency. However, the Mexican finance ministry documents expenditures of the central government at monthly frequency. These are classified into "current" and "capital" expenditures. Summing sub-categories within the "current" category, one can obtain a measure of expenditures that could be classified as government consumption (total compensation of employees, purchases of materials and supplies, purchases of services). From sub-categories within the "capital" category, one can similarly obtain a measure of gross fixed capital formation (government investment). A country-by-country description of data sources is available in Appendix A2 and Appendix Tables A1-A2.

The main specification in our empirical analysis includes real government consumption, GDP, the ratio of the current account to GDP and the real effective exchange rate. Other specifications include real government investment, and the short-term interest rate targeted by the central bank. Nominal data was deflated using the corresponding deflator, when available, and using the CPI index when such a deflator was not available; using a GDP deflator instead of CPI for those countries where both were available left the paper's results unchanged. We took natural logarithms of all government expenditure and GDP data and of the real effective exchange rate.

The data show strong seasonal patterns. Our selected de-seasonalization method was the SEATS algorithm (see Gómez and Maravall, 2000). In an earlier version of this study, we used the X-11 algorithm and obtained similar results. All variables were non-stationary, with the exception of the central bank interest rate and the ratio of the current account to GDP. The data used in the reported regressions are deviations of the non-stationary variables from 
their quadratic trend. Using a linear trend yielded similar results. The current account and the policy interest rate were included in levels, while the real exchange rate was included in first differences. After detrending the data, the series were stationary, with unit roots rejected at the 99 percent confidence level for all variables in both an Augmented Dickey-Fuller test and the Im, Pesaran, and Shin (2003) test.

With this new dataset, a decade or more of quarterly observations is now available for a cross-section of 44 countries, of which 24 are developing countries. While ten years (40 observations) of data are hardly enough to estimate the effect of fiscal policy on output for an individual country, the pooled data contains more than 2,500 observations-an order of magnitude greater than used in VAR studies of fiscal policy to date.

Table 1 provides summary statistics for the main new variable in the dataset: quarterly government consumption. The table reports the proportion of government consumption to GDP, the autocorrelation of (detrended) government consumption, and the variance of (detrended) government consumption relative to the variance of GDP. These statistics are calculated for a number of country groupings, which will be used in the empirical analysis of the following sections. The proportion of GDP devoted to government consumption varies from 9.6 percent in El Salvador to 27.4 percent in Sweden during the sample period. This reflects the larger government size (with government consumption averaging 20.8 percent) in high income countries than in developing countries (15.6 percent).

There is also a difference between high-income and developing countries in the persistence of government consumption. The cyclical component of government consumption has an autocorrelation coefficient of 0.74 in high income countries, compared with 0.6 in developing countries. With respect to volatility, the greatest difference appears again in comparing developing to high-income countries. In both groups of countries, government consumption is more variable than GDP. However, in developing countries government consumption is more than six times more volatile than output, compared to a factor of two in high-income countries. 


\section{Empirical Analysis and Results}

\subsection{Estimation Methodology}

Following Blanchard and Perotti (2002), we estimate the following system of equations:

$$
A Y_{n, t}=\sum_{k=1}^{K} C_{k} Y_{n, t-k}+B u_{n, t}
$$

where $Y_{n, t}$ is a vector of variables comprising government expenditure variables (e.g., government consumption and/or investment), GDP, and other endogenous variables for a given quarter $t$ and country $n$. $C_{k}$ is a matrix of the own- and cross-effects of the $k^{t h}$ lag of the variables on their current observations. The matrix $B$ is diagonal, so that the vector $u_{t}$ is a vector of orthogonal, i.i.d. shocks to government consumption and output such that $E u_{n, t}=0$ and $E\left[u_{n, t} u_{n, t}^{\prime}\right]$ is the identity matrix. Finally, the matrix $A$ allows for the possibility of simultaneous effects among the endogenous variables $Y_{n, t}$. We assume that the matrices $A, B$, and $C_{k}$ are invariant across time and countries in given regression.

System (1) is estimated by Panel OLS regression with fixed effects. OLS provides us with estimates of the matrices $A^{-1} C_{k}$. As is usual in SVAR estimation of this system, additional identification assumptions are required to estimate the coefficients in $A$ and $B$. In our benchmark regressions $Y_{n, t}=\left(g_{n, t}, y_{n, t}, C A_{n, t}, d R E E R_{n, t}\right)^{\prime}$, where $g_{n, t}$ is government consumption, $y_{n, t}$ output, $C A_{n, t}$ the ratio of the current account balance to GDP, and $d R E E R_{n, t}$ the change in the natural logarithm of the real effective exchange rate. We follow Blanchard and Perotti (2002) in assuming that changes in government consumption require at least one quarter to respond to innovations in other macroeconomic variables. Our remaining identifying assumptions apply a Cholesky decomposition, where we follow Kim and Roubini (2008) and others in ordering the remaining variables after GDP and ordering the current account balance before the real effective exchange rate. The ordering of these two additional controls in any sequence, while retaining the identifying assumption of the lagged response of discretionary fiscal policy to macroeconomic variables, had virtually no effect on reported results. While we include the current account and the real exchange rate as controls, results are virtually identical when these controls are excluded. In addition, it is reassuring that our identified shocks-the estimated government consumption and GDP residuals from the 
VAR-are highly correlated when the controls are included and when they are excluded. ${ }^{7}$

We do not control for tax policy. Ignoring the tax-expenditure mix of fiscal policy and the response of tax policy to shocks to both government consumption and output could, in principle, bias our results. We omit tax variables due to data limitations. However, Ilzetzki (2011) shows that controlling for tax policy does not significantly alter our results for countries overlapping between his study and ours. This suggests that the bias due to this omitted variable is not substantial in practice.

We choose to pool the data across countries rather than provide estimates on a countryby-country basis. With the exception of a handful of countries, the sample for a typical country is of approximately ten years, yielding around forty observations. We exploit the larger sample size-almost always exceeding one thousand observations-delivered from pooling the data. We divide the sample into a number of country-observation groupings and estimate and compare the fiscal multiplier across categories.

\subsection{Fiscal Multipliers: Definitions}

There are several ways to measure the fiscal multiplier and a few definitions are useful. In general, the definition of the fiscal multiplier is the change in real GDP or other output measure caused by a one-unit increase in a fiscal variable. For example, if a one dollar increase in government consumption causes a fifty cent increase in GDP, then the government consumption multiplier is 0.5 .

Multipliers may differ greatly across forecast horizons. We therefore focus on two specific fiscal multipliers. The Impact Multiplier, defined as

$$
\text { Impact Multiplier }=\frac{\Delta y_{0}}{\Delta g_{0}},
$$

measures the ratio of the change in output to a change in government expenditure at the moment the impulse to government expenditure occurs. In order to assess the effect of fiscal policy at longer forecast horizons, we also report the Cumulative Multiplier at time T,

\footnotetext{
${ }^{7}$ Regressing the residuals from these two specifications on each other yields a coefficient of 1 with tstatistics exceeding 100. This result is reassuring, as it indicates that additional controls do not affect our view on the predictability of fiscal shocks in our VAR.
} 
defined as

$$
\text { Cumulative Multiplier }(T)=\frac{\sum_{t=0}^{T}(1+i)^{-t} \Delta y_{t}}{\sum_{t=0}^{T}(1+i)^{-t} \Delta g_{t}},
$$

where $i$ is the median interest rate in the sample. We use the median rather than the average to avoid placing excessive weight on extreme events, or particular countries (e.g. Brazil, Turkey) with unusually high interest rates. This measures the net present value of the cumulative change in output per unit of additional government expenditure, also in net present value, from the time of the impulse to government expenditure to the reported horizon. ${ }^{8}$ A cumulative multiplier that is of specific interest is the Long-Run Multiplier defined as the cumulative multiplier as $T \rightarrow \infty$.

\subsection{Lag Structure}

In choosing $\mathrm{K}$, the number of lags included in system (1), we conducted a number of specification tests. As is often the case, the optimal number of lags varies greatly across countrygroups and tests. In VAR analyses, results often change significantly depending on the number of lags chosen in the VAR. For simplicity, and to assure the reader that differences across country groups are not driven by differences in selected lags, we set $K=4$ in all reported results.

It is reassuring that all of the paper's results are robust to choosing any alternative number of lags from 1 to 8 . Using a more formal criterion to select the lag length of each regression does not alter our results. We report in Appendix Figures A6 to A12 our main results when the number of lags in each regression is chosen separately according to the Akaike information criterion. Results are similar as are results obtained when lags are chosen by other criteria, or using a pretest data-based model selection.

\footnotetext{
${ }^{8}$ This definition follows Mountford and Uhlig (2011). Our results are not driven by differences in interest rates across regressions. In earlier versions of this paper we reported cumulative multipliers without discounting $(i=0)$ with similar results.
} 


\subsection{High-income and developing countries}

As a first cut at the data, we divided the sample into high-income and developing countries. ${ }^{9}$ Figures 1 and 2 show the impulse responses of all endogenous variables to a 1 percent shock to government consumption at time 0 . Dashed lines give the 90 percent confidence intervals, based on Monte Carlo estimated standard errors, with 1000 repetitions. Figure 1 presents responses for high-income countries and Figure 2 for developing countries. A few differences stand out between the impulse responses. First, the impact response of output to government spending is positive and statistically significant from zero in high-income countries (0.08 percent), but is negative in developing countries (-0.01 percent). The difference between the responses of GDP to government consumption in the two groups of countries is statistically significant at the 95 percent confidence level. Second, GDP's response is positive throughout the simulation in high income countries, while it is negative in the long run in developing countries. Third, while the real exchange rate is barely affected on impact by the shock to government consumption in high-income countries and shows a depreciation in the long run, the real exchange rate appreciates by a statistically significant margin in developing countries on impact. ${ }^{10}$

Based on the impulse responses depicted in Figures 1 and 2, we can compute the corresponding fiscal multipliers, using the definitions of Section 3.2 These are shown in Figure 3. The impact multiplier for high-income countries is 0.39 . An additional dollar of government spending delivers only 39 cents of additional output in the quarter of implementation. This effect, while small, is statistically significant. For developing countries, the impact multiplier

\footnotetext{
${ }^{9}$ We use the World Bank's classification of high income countries in 2000, and include all other countries in the category "developing". The marginal countries are the Czech Republic, defined as developing in 2000, but high-income in 2006; and Slovenia, categorized as high-income in 2000, but as "upper-middle income" (and thus developing by our typology) before 1997. Excluding or reclassifying these two countries does not alter the results. Israel is classified as high income, based on this definition, but was categorized as an "emerging market" in J.P. Morgan's EMBI index. Excluding or reclassifying Israel does not alter the results.

${ }^{10}$ Kim and Roubini (2008); Ravn, Schmitt-Grohe, and Uribe (2007); and Monacelli and Perotti (2008) all document a depreciation in the real exchange rate in response to government consumption shocks in subsets of our high-income sample. We obtain a similar result in the long run. The two latter papers provide theories wherein non-standard preferences lead to this outcome. This would imply, however, differences in preferences between agents in high-income and developing countries. A possible alternative explanation for this difference is that real exchange rate movements in industrialized countries reflect mainly changes in exchange-rate-adjusted relative prices of tradable goods, while in developing countries there is an important component due to fluctuations in the relative price of non-tradable goods relative to tradables. Government consumption is mainly in the form of non-tradables, so an increase in government consumption pushes up the relative price of non-tradables and the real exchange rate.
} 
is negative at -0.03 and is not statistically significant from zero. The difference between the impact multiplier in the two groups of countries is statistically significant at the 95 percent confidence level.

Focusing on the impact multiplier, however, may be misleading because fiscal stimulus packages can only be implemented over time and there may be lags in the economy's response. We see that the cumulative multiplier for high-income countries rises to a long-run value of 0.66. Even after the full impact of a fiscal expansion is accounted for, output has risen less than the cumulative increase in government consumption, implying some crowding out of output by government consumption at every time horizon. The multiplier is statistically different from zero at every horizon. On the other hand, the cumulative long-run multiplier for developing countries is negative and not statistically significant from zero at any horizon. Government consumption is more-than-fully crowded out by other components of GDP (investment, consumption, or net exports) in the long run.

\subsection{Exchange rate regimes}

As a second cut at the data, we divided our sample of 44 countries into episodes of predetermined exchange rates and those with more flexible exchange rate regimes. We use the de facto classification of Ilzetzki, Reinhart, and Rogoff (2008) to determine the exchange rate regime of each country in each quarter. Table A3 lists for each country the episodes in which the exchange arrangement was classified as fixed or flexible. ${ }^{11}$

The cumulative multipliers, shown in Figure 4, suggest that the exchange rate regime matters a great deal. Under predetermined exchange rates, the impact multiplier is 0.15 (and statistically significantly different from zero) and rises to 1.4 in the long-run. Under flexible exchange rate regimes, however, the multiplier is negative at any forecast horizon, and statistically significant from zero both on impact and in the long run. The difference between the outcome for the two groups is statistically significant at any forecast horizon.

These results are, in principle, consistent with the Mundell-Fleming model, which pre-

\footnotetext{
${ }^{11}$ We divided the sample into country-episodes of predetermined exchange rates. For each country we took any 8 continuous quarters when the country had a fixed exchange rate as a "fixed" episode and any 8 continuous quarters or more when the country had flexible exchange rates as "flex". As fixed we included countries with no legal tender, hard pegs, crawling pegs, and de facto or pre-anounced bands or crawling bands with margins no larger than $+/-2 \%$. All other episodes were classified as flexible. Based on this definition, Eurozone countries are included as having fixed exchange rates.
} 
dicts that fiscal policy is effective in raising output under predetermined exchange rates but ineffective under flexible exchange rates. In the textbook version, a fiscal expansion increases output, raises interest rates, and induces an inflow of foreign capital, which creates pressure to appreciate the domestic currency. Under predetermined exchange rates, the monetary authority expands the money supply to prevent this appreciation. Monetary policy accommodates the rise in output. Under flexible exchange rates, however, the monetary authority keeps a lid on the money supply and allows the real exchange rate appreciation to reduce net exports. Output does not change because the increase in government spending is exactly offset by the fall in net exports.

The broader monetary context of the fiscal stimuli is explored in Figure 5. This figure reports impulse responses to a 1 percent shock to government consumption in a VAR that now includes a fifth variable: the short-term interest rate set by the central bank. We exclude this variable from our baseline regressions, as its inclusion reduces our sample by 20 percent, but all results are robust to its inclusion as an additional endogenous variable. ${ }^{12}$

The first row of Figure 5 presents government consumption shocks in episodes of fixed and flexible exchange rates. The second row presents the response of GDP to these shocks. Although the impulses to government consumption are broadly similar, the increase in GDP is positive and statistically significant under fixed exchange rates, but negative and statistically insignificant under flexible exchange rates.

The following two rows explore the traditional Mundell-Fleming channel. They show the response of the current account as a percentage of GDP (third row) and the real effective exchange rate (fourth row). We find only weak evidence for the traditional channel. As expected, the real exchange rate appreciates on impact under flexible exchange rates, but by a statistically insignificant margin under fixed exchange rates. But this does not translate into a larger decline in the current account in episodes where the exchange rate was flexible, as the Mundell-Fleming model would predict.

On the other hand, we do find evidence for the "monetary accommodation" channel,

\footnotetext{
${ }^{12}$ In the reported results, we order the central bank's policy rate after government consumption, but before other macroeconomic variables. The ordering of the fiscal variable before the central bank's instrument follows from the assumption that the monetary authority can respond more rapidly to news than fiscal decision-makers can. Results are virtually unchanged if the policy interest rate is ranked lower in the Cholesky ordering. However, the response of the interest rates is significantly weakened if the ordering of the fiscal and monetary variables is reversed.
} 
as shown in fifth row of Figure 5. Monetary authorities operating under predetermined exchange rates lower the policy interest rate by a cumulative 30 basis points in the year following a government consumption shock of 1 percent of GDP. In contrast, central banks operating under flexible exchange rates increase the policy interest rate by a statistically significant margin on impact, with interest rates increasing an average of 25 basis points within the year following a fiscal shock of similar magnitude.

Our results are related to the notion that monetary accommodation plays an important role in determining the expansionary effect of fiscal policy. Davig and Leeper (2011), for example, show in a DSGE model with nominal rigidities that the effect of fiscal policy differs greatly depending on whether monetary policy is active or passive. Coenen et al (2010) show that monetary accommodation is an important determinant of the size of fiscal multipliers in seven different structural models used in policymaking institutions. This result also relates indirectly to the theoretical studies of Christiano, Eichenbaum, and Rebelo (2011) and Erceg and Lindé (2010), who show that fiscal multipliers are larger when the central bank's policy interest rate is at the zero lower bound.

We find that differences in monetary accommodation are a potential explanation for differences in the magnitude of fiscal multipliers across exchange rate regimes. But the weak evidence on differences in the response of the current account raises the question as to which components of GDP differ in their response across monetary regimes. The insignificant difference in current account response implies via GDP accounting that either consumption or investment must differ in its response across these regimes. In a new set of regressions, we replaced GDP with two variables: private consumption and private investment. ${ }^{13}$ Data availability restricted our attention to OECD countries and a small number of Latin American countries. Nevertheless, Figure 6 shows that there is a marked difference in the response of private consumption to government consumption shocks across exchange rate regimes. Consumption, shown in the first row of the figure, responds positively to a shock in government consumption under fixed exchange rates, but negatively under flexible exchange rates. The responses are statistically significant in both cases. The response of investment is similar under either predetermined or flexible exchange rate regimes. In both cases, the response is

\footnotetext{
${ }^{13}$ Consistent with our earlier identifying assumption, we do not allow for a contemporaneous response of government consumption to unpredicted shocks to private consumption or private investment. The ordering of the latter two variables among the other variables in the VAR system did not affect the results reported here.
} 
erratic and investment declines by a statistically significant margin on impact.

This result is related to the debate on the response of private consumption to government consumption shocks. Perotti (2004a, 2007), using a VAR framework similar to ours, finds a positive response of private consumption to government consumption. In contrast, Ramey (2011a) finds that private consumption declines in response to military expenditure shocks. While the focus in this debate has been on how to identify shocks to public expenditure, our results point to an additional potential explanation of these contrasting findings. Both approaches have ignored the interaction between fiscal and monetary policy. Once we control for monetary policy, we find that consumption responds positively to government consumption shocks only when the central bank accommodates the fiscal shock. Further exploration of fiscal-monetary interactions might shed more light on the response of macroeconomic variables to government expenditure shocks.

\subsection{Openness to trade}

Next, we divide our sample of 44 countries based on their ratio of trade (imports plus exports) to GDP. As shorthand, we label an economy as "open" if this ratio exceeded 60 percent. If foreign trade is less than 60 percent of GDP, we defined the country as "closed". A list of "open" and "closed" economies by this classification is shown in Appendix Table A4. Minor variations of this threshold did not significantly affect our results. Using this criterion, 28 countries are classified as "open" and the remaining 16 are classified as "closed".

The cumulative responses, shown in Figure 7, indicate the volume of trade as a proportion of GDP is a critical determinant of the size of the fiscal multiplier. For economies with low trade-GDP ratios, the impact response is 0.6 and the long-run multiplier is 1.1, with multipliers statistically significant from zero at all forecast horizons. For economies with high trade volumes as a proportion of GDP, the impact response is negative both on impact and in the long run and never statistically significant from zero. The difference between the two categories is statistically significant at forecast horizons of up to five years.

This definition of trade openness conflates two main factors that affect the proportion of trade in a country's GDP. A country may have a low ratio of trade to GDP because it has high tariffs or other barriers to trade, or because it is a large economy with a relatively large internal market. We find, however, that both factors affect the magnitude of the fiscal 
multiplier independently.

In defining openness based on legal restrictions to trade, we divided the sample into periods where the weighted mean of tariffs across all products in a country exceeded 3.6 percent and those where it was lower than this threshold, according to the World Bank's World Development Indicators. The median of this tariff in our sample was 3.6 percent. "Open" and "closed" economies in our sample based on this definition summarized in Appendix Table A5. When defining openness to trade based on this criterion, we found a similar difference between the multiplier in countries open and closed to trade. Results are shown in Appendix Figure A1.

We then divided our sample into the ten largest economies (in terms of their total GNP in U.S. dollars) on the one hand and the remaining countries on the other. ${ }^{14}$ We find that the fiscal multiplier is larger in large economies relative to small, with a long-run multiplier of approximately 1 in the former and -0.2 in the latter. Results are shown in Appendix Figure A2

As before, this result is consistent with the textbook Mundell-Fleming model. In such a model, the fiscal multiplier would be lower in a more open economy because part of the increase in aggregate demand would be met by a reduction in net exports rather than by an increase in domestic production.

\subsection{Financial fragility}

With debt burdens rapidly accumulating during the current global economic turmoil, and several countries teetering on the verge of default, some countries have opted for fiscal stimulus while others have chosen to adopt fiscal austerity measures. It is natural to ask how the level of sovereign debt affects the impact of government consumption stimulus on GDP. To this effect, we built a sample of country-episodes where the ratio of the total debt of the central government exceeded 60 percent of GDP. A list of "high-debt" episodes is provided in Appendix Table A6.

Figure 8 shows the resulting cumulative multiplier during periods of high debt burden. Our estimates are consistent with the notion that attempts at fiscal stimulus in highly in-

\footnotetext{
${ }^{14}$ Based on this threshold, countries with GNPs greater than or equal to that of Australia were considered "large." The Netherlands was the largest economy classified as "small."
} 
debted countries may actually be counter-productive. Our estimate for the impact multiplier is close to zero, and we estimate a long run multiplier of -3 . Moreover, we can reject with $99 \%$ confidence the hypotheses that the fiscal multiplier is positive. We are reassured that this result is not spurious by the fact that this long run multiplier remains negative when the threshold is set to 60 or 70 percent of GDP, while it becomes positive for debt-to-GDP ratios of 30 or 40 percent. But experimenting with different thresholds indicated that the 60 percent threshold was a meaningful cutoff, above which fiscal stimulus appears ineffective.

These results are consistent with the idea that debt sustainability is an important factor in determining the output effect of government purchases. When debt levels are high, increases in government expenditures may act as a signal that fiscal tightening will be required in the near future. Moreover, as recent events in southern Europe and Ireland illustrate, these adjustments may need to be sudden and large. The anticipation of such adjustment could have a contractionary effect that would tend to offset whatever short-term expansionary impact government consumption may have. Under these conditions, fiscal stimulus may therefore be counter-productive.

\subsection{Government Investment}

While our focus so far has been on government consumption-due in part to limited availability of government investment data-it is nevertheless interesting to see whether the effects of government investment differ from those of government consumption. To explore this question, we estimate (1), this time with $Y_{n, t}=\left[g_{n, t}^{I}, g_{n, t}, y_{n, t}\right]^{\prime}$ where $g_{n, t}^{I}$ is real government investment, and $g_{n, t}$ is real government consumption and $y_{n, t}$ is GDP. We follow Perotti (2004b) in ordering government investment before government consumption in the Cholesky decomposition, although results are not altered if the ordering is reversed. The number of countries in the sample declines when including government investment, but the results for government consumption reported in the previous sections hold roughly for this sub-sample as well. We control in these regressions for government consumption, but follow Perotti (2004b) in estimating the multiplier to "pure" government investment shocks, that prevent endogenous responses of government investment and GDP to government consumption. This is done by estimating the full system with the three endogenous variables, but setting all values of $g_{n, t}=0$ in forecasts of $g_{n, t}^{I}$ and $y_{n, t}$ in impulse responses. This is done to ensure that 
we are not confusing the response of GDP to government investment with that to government consumption, as the two public spending variables co-move strongly. ${ }^{15}$

The resulting cumulative multipliers for high-income countries and developing countries are presented in Figure 9. Point estimates for the government investment multiplier in highincome countries are reported in the upper panel. Estimates at all horizons are similar to the government consumption multipliers of Figure 3. We have no robust evidence that government investment is more productive in its stimulative effect in high-income countries. This is consistent with the findings of Perotti (2004b).

In developing countries, in contrast, the lower panel of Figure 9 shows the impact multiplier of government investment is 0.6 and statistically significant. We can reject at the 90 percent confidence level the hypothesis that the effect of government investment is no higher than that of government consumption horizons of up to 10 quarters. It appears that the composition of government purchases is an important determinant of the impact of government spending shocks on output in developing countries.

When breaking up the sample between predetermined and flexible exchange rates, open and closed economies, and countries with high debt-to-GDP ratios, we find results for the pure government investment multiplier that are roughly in line with those for government consumption, although differences across groups are no longer statistically significant, and multipliers are slightly higher than those for government consumption. See figures A3 and A4 in the Appendix for the results.

\section{Conclusions}

This paper is an empirical exploration of one of the central questions in macroeconomic policy in the past few years: what is the effect of government purchases on economic activity? We use panel SVAR methods and a novel dataset to explore this question. Our results point to the fact that the size of fiscal multipliers critically depends on key characteristics of the

\footnotetext{
${ }^{15}$ In principle one might wish to control for public investment in estimates of public consumption multipliers. However, the omission of the latter from earlier regressions does not have a significant impact on the estimate of government consumption multipliers. This is because, in all countries in our sample, government investment is small relative to government consumption. In addition, results in this section are qualitatively the same when reporting the multiplier when government consumption is not forced to zero along simulation paths.
} 
economy under study.

We have found that the effect of government consumption is very small on impact in most cases. This suggests that increases in government purchases may be rather slow in impacting economic activity, which raises questions as to the usefulness of discretionary fiscal policy for short-run stabilization purposes. The medium- to long-run effects of increases in government consumption vary considerably: in economies closed to trade or operating under fixed exchange rates we find a substantial long-run effect of government consumption on economic activity. In contrast, in economies open to trade or operating under flexible exchange rates, a fiscal expansion leads to no significant output gains. Further, fiscal stimulus may be counterproductive in highly-indebted countries. Indeed, in countries with debt levels as low as 60 percent of GDP, government consumption shocks may have strong negative effects on output.

The composition of government expenditure appears to impact its stimulative effect, particularly in developing countries. While increases in government consumption decrease output on impact in this set of countries, increases in government investment cause an increase in GDP, both on impact and in the long run.

With the increasing importance of international trade in economic activity, and with many economies moving towards greater exchange rate flexibility (typically in the context of inflation targeting regimes), our results suggest that seeking the Holy Grail of fiscal stimulus could be counterproductive, with little benefit in terms of output and potential long-run costs due to larger stocks of public debt. Moreover, fiscal stimuli are likely to become weaker, and potentially yield negative multipliers, in the near future, because of the high debt ratios observed in countries, particularly in the industrialized world.

On the other hand, emerging countries-particularly larger economies with some degree of "fear of floating"-would be well served if they stopped pursuing procyclical fiscal policies. Indeed, emerging countries have typically increased government consumption in good times and reduced it in bad times, thus amplifying the underlying business cycle-what Kaminsky, Reinhart, and Végh (2004) have dubbed the "when it rains, it pours" phenomenon. The inability to save in good times greatly increases the probability that bad times will turn into a full-fledged fiscal crisis. Given this less-than-stellar record in fiscal policy, an a-cyclical fiscal policy-whereby government consumption and tax rates do not respond to the business cycle--would represent a major improvement in macroeconomic policy. While occasional rain 
may be unavoidable for emerging countries, significant downpours would be relegated to the past.

\section{References}

[1] Auerbach, Alan J. and Yuriy Gorodnichenko (2011) "Fiscal Multipliers in Recession and Expansion" NBER Working Paper 17447.

[2] Auerbach, Alan J., and Yuriy Gorodnichenko (2012) "Measuring the Output Responses to Fiscal Policy," forthcoming in the American Economic Journal - Economic Policy

[3] Barro, Robert J. (1981), "Output effects of government purchases," Journal of Political Economy 89, 1086-1121.

[4] Barro, Robert J. (2009), "Government spending is no free lunch," Wall Street Journal (January 22).

[5] Beetsma, Roel, Massimo Giuliodori, and Franc Klaassen (2008), "The effects of public spending shocks on trade balances and budget deficits in the European Union," Journal of the European Economic Association 6(2-3).

[6] Blanchard, Olivier and Roberto Perotti (2002), "An empirical characterization of the dynamic effects of changes in government spending and taxes on output," Quarterly Journal of Economics 117: 4, 1329-1368.

[7] Coenen, Günter, Christopher Erceg, Charles Freedman, Davide Furceri, Michael Kumhof, René Lalonde, Douglas Laxton, Jesper Lindé, Annabelle Mourougane, Dirk Muir, Susanna Mursula, Carlos de Resende, John Roberts, Werner Roeger, Stephen Snudden, Mathias Trabandt and Jan in 't Veld (2010), "Effects of fiscal stimulus in structural models," IMF Working Paper 10/73.

[8] Corsetti, Giancarlo, André Meier, and Gernot J. Müller (2011), "What determines government spending multipliers?" Mimeo: Cambridge University, International Monetary Fund, and University of Bonn. 
[9] Christiano, Lawrence, Martin Eichenbaum and Sergio Rebelo (2011), "When is the Government Spending Multiplier Large?" Journal of Political Economy 119 (1), 78-121

[10] Davig, Troy, and Eric Leeper (2011), "Monetary-Fiscal Policy Interactions and Fiscal Stimulus," European Economic Review 55(2).

[11] Erceg, Christopher, and Jesper Lindé (2010), "Is there a fiscal free lunch in a liquidity trap?" (mimeo, Board of Governors of the Federal Reserve).

[12] Eurostat (2006), Manual on quarterly non-financial accounts for general government (European Commission and Eurostat).

[13] Fatás, Antonio and Ilian Mihov (2001), "The effects of fiscal policy on consumption and employment: Theory and evidence," CEPR Discussion Papers 2760.

[14] Gómez, Victor and Augstín Maravall (2000), "Seasonal adjustment and signal extraction in economic time series" in Daniel Peña, George C. Tiao, and Ruey S. Tsay, eds. A Course in Time Series Analysis.

[15] Ilzetzki, Ethan (2011), "Fiscal policy and debt dynamics in developing countries," Policy Research Working Paper Series 5666, The World Bank.

[16] Ilzetzki, Ethan, Carmen Reinhart and Kenneth Rogoff (2009), "Exchange rate arrangements entering the 21st century: Which anchor will hold?" (mimeo, University of Maryland and Harvard University).

[17] Ilzetzki, Ethan and Carlos A. Végh (2008), "Procyclical fiscal policy in developing countries: Truth or fiction?" NBER Working Paper No. 14191.

[18] Im, Kyung So, M. Hashem Pesaran and Yongcheol Shin (2003), "Testing for unit roots in heterogeneous panels," Journal of Econometrics, 115:1.

[19] IMF (2007). The Special Data Dissemination Standard. Guide for Subscribers and users. International Monetary Fund.

[20] Kaminsky, Graciela, Carmen Reinhart, and Carlos Vegh (2004), "When it rains, it pours: Procyclical capital flows and macroeconomic policies," NBER Macroeconomics Annual. 
[21] Kim, Soyoung and Nouriel Roubini (2008), "Twin deficit or twin divergence? Fiscal policy, current account, and real exchange rate in the U.S," Journal of International Economics 74:2

[22] Kraay, Aart (2010) "How Large is the Government Spending Multiplier? Evidence from World Bank Lending." World Bank Policy Research Working Paper 5500.

[23] Nakamura, Emi, and Jon Steinsson (2011) "Fiscal Stimulus in a Monetary Union: Evidence from U.S. Regions," NBER Working Papers 17391.

[24] Monacelli, Tomasso and Roberto Perotti (2008), "Fiscal Policy, Wealth Effects, and Markups," NBER Working Papers 14584.

[25] Mountford, Andrew and Harald Uhlig (2009), "What are the effects of fiscal policy shocks?," Journal of Applied Econometrics 24(6).

[26] Parker, Jonathan "On Measuring the Effects of Fiscal Policy in Recessions," Journal of Economic Literature, 49(3).

[27] Perotti, Roberto (1999), "Fiscal policy in good times and bad," Quarterly Journal of Economics, 114(4).

[28] Perotti, Roberto (2004a), "Estimating the effects of fiscal policy in OECD countries" (mimeo, Bocconi University).

[29] Perotti, Roberto (2004b), "Public investment: another (different) look" (mimeo, Bocconi University).

[30] Perotti, Roberto (2007), "In search of the transmission mechanism of fiscal policy," NBER Working Paper No. 13143.

[31] Ramey, Valerie A. (2011a), "Identifying government spending shocks: It's all in the timing," Quarterly Journal of Economics 126(1).

[32] Ramey, Valerie A. (2011b), "Can Government Purchases Stimulate the Economy?" Journal of Economic Literature, 49(3). 
[33] Ramey, Valerie A. and Matthew D. Shapiro (1998), "Costly capital reallocation and the effects of government spending," Carnegie-Rochester Conference Series on Public Policy, Elsevier, vol. 48(1),145-194.

[34] Ravn, Morten O., Stephanie Schmitt-Grohé and Martín Uribe (2007), "Explaining the Effects of Government Spending Shocks on Consumption and the Real Exchange Rate," NBER Working Papers 13328.

[35] Romer, Christina, and Jared Bernstein (2009), "The job impact of the American recovery and reinvestment plan" (Council of Economic Advisers).

[36] Wilson, Daniel (2011) "Fiscal Spending Jobs Multipliers: Evidence from the 2009 American Recovery and Reinvestment Act," forthcoming in the American Economic Journal - Economic Policy. 


\section{A Appendix}

\section{A.1 Are innovations to government consumption foreseen?}

Following Blanchard and Perotti (2002), our estimation methodology assumes that residuals from a VAR regression are not anticipated. In a critique of this approach, Ramey (2011a) shows that fiscal shocks identified through VAR residuals are predicted by private forecasts in the United States. A similar exercise is difficult to conduct in the case of developing countries because there is little documentation of private sector expectations of fiscal policy. But there is reason to believe that fiscal shocks are harder to foresee in the case of developing countries. As illustrated in Table 1, government consumption is significantly more volatile in developing countries than in high-income countries.

We provide suggestive evidence that these shocks were not foreseen. We do so by using data revisions by a number of central banks, for which (very short) time series of government consumption data of different vintages are available. These are shown in Figure A5 for Bulgaria, Ecuador, and Uruguay. The dotted markers indicate the error in the central bank's preliminary estimate of government consumption in a given quarter. This is calculated as the difference (in percent) between the final published data by the central bank and the first published official estimate (typically the quarter following the data point). The circle markers are the residuals from the government consumption equation in the VAR (for developing countries). While the availability of vintage data is limited, the short time-series available show a very clear correlation between the central bank's estimation error and the VAR residuals. This suggests that VAR residuals are a fairly good measure of unexpected innovations in government consumption. It is extremely unlikely that the information set of the private sector prior to shocks to government consumption was better than that of the central bank after the shock. Further, in developing countries, fiscal policy is sufficiently erratic that even ex-post estimates are subject to significant revision in following years. We find this evidence suggestive of the fact that, at least in developing countries, VAR residuals do capture a significant portion of unanticipated shocks to government consumption. 


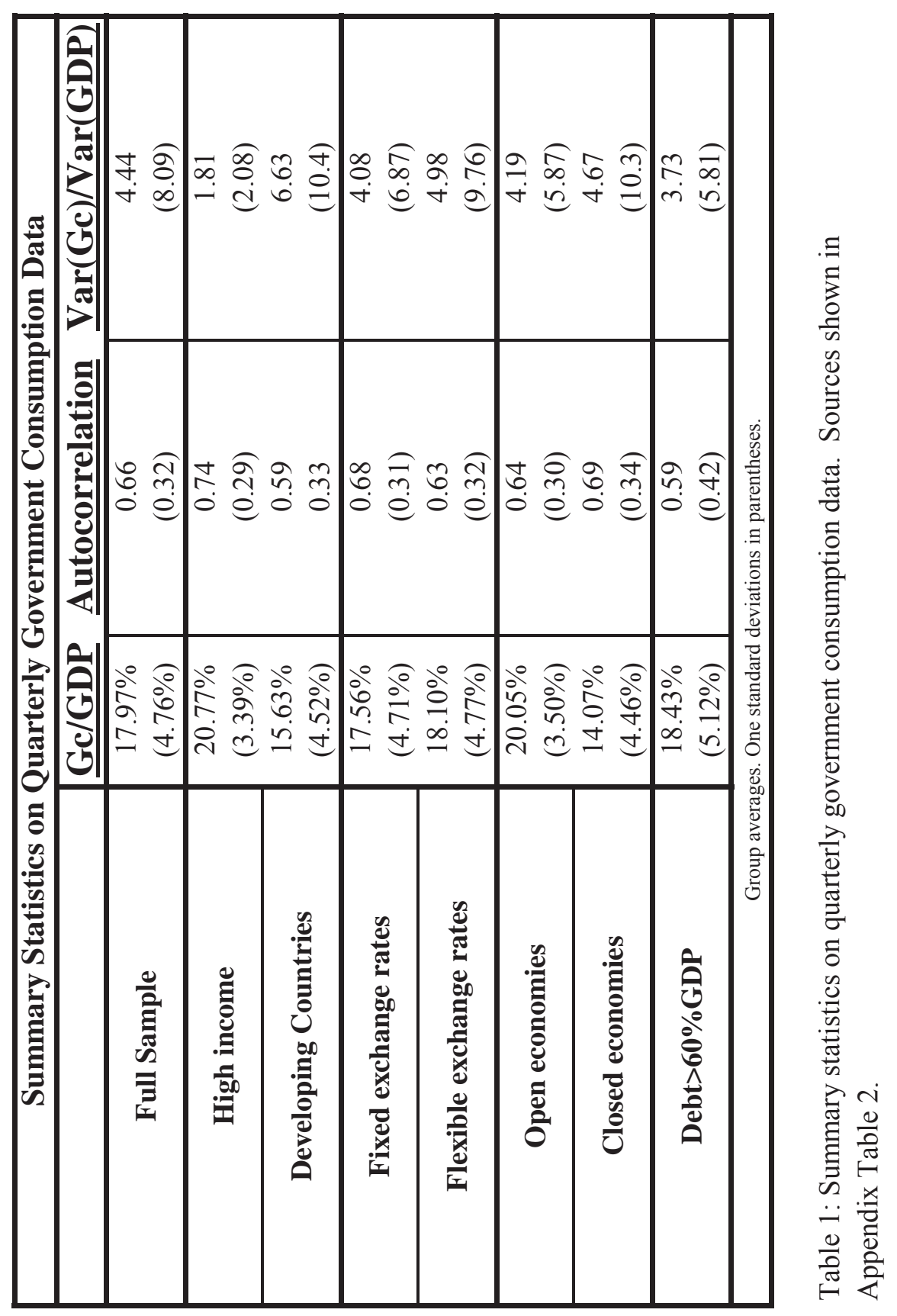



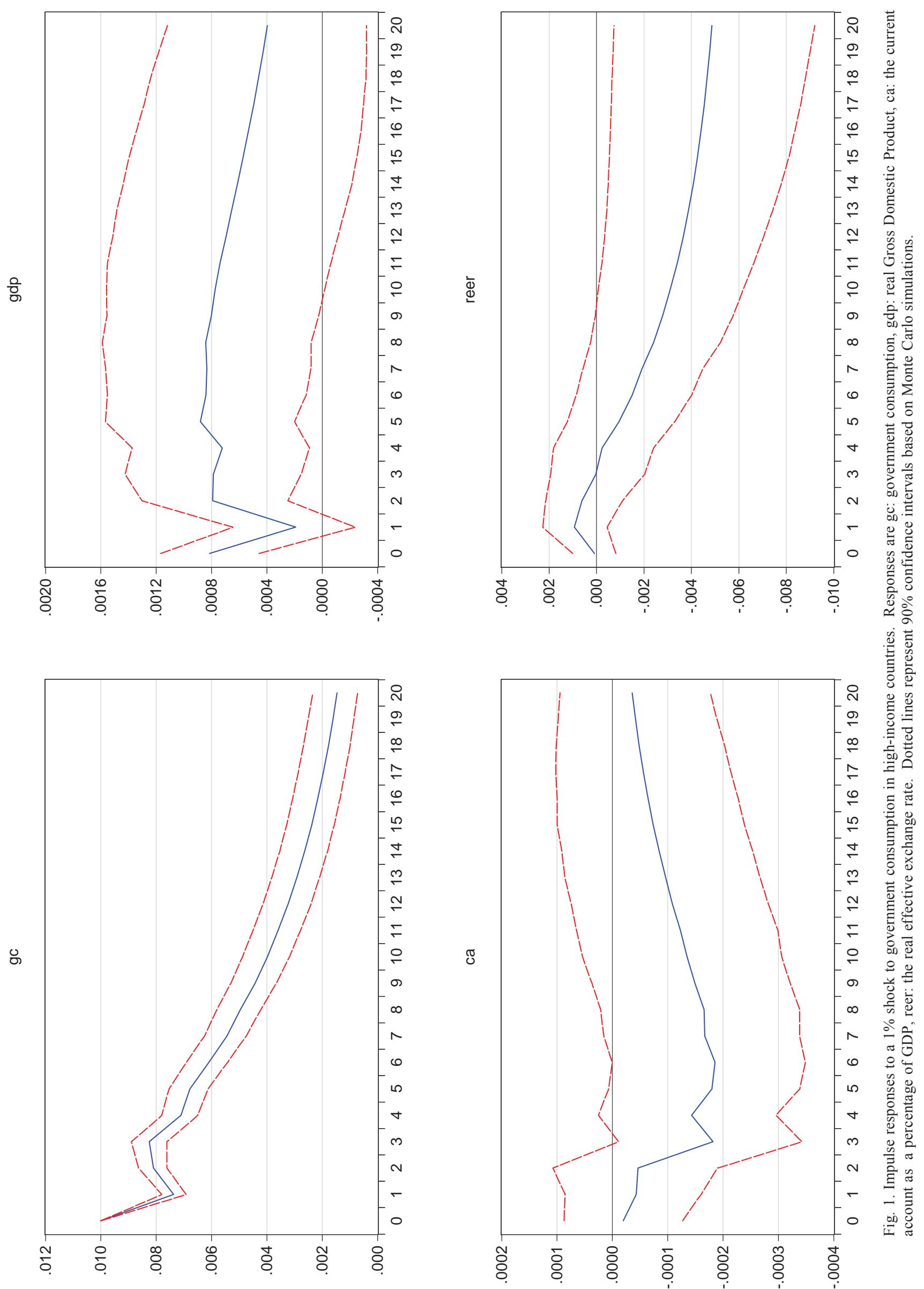

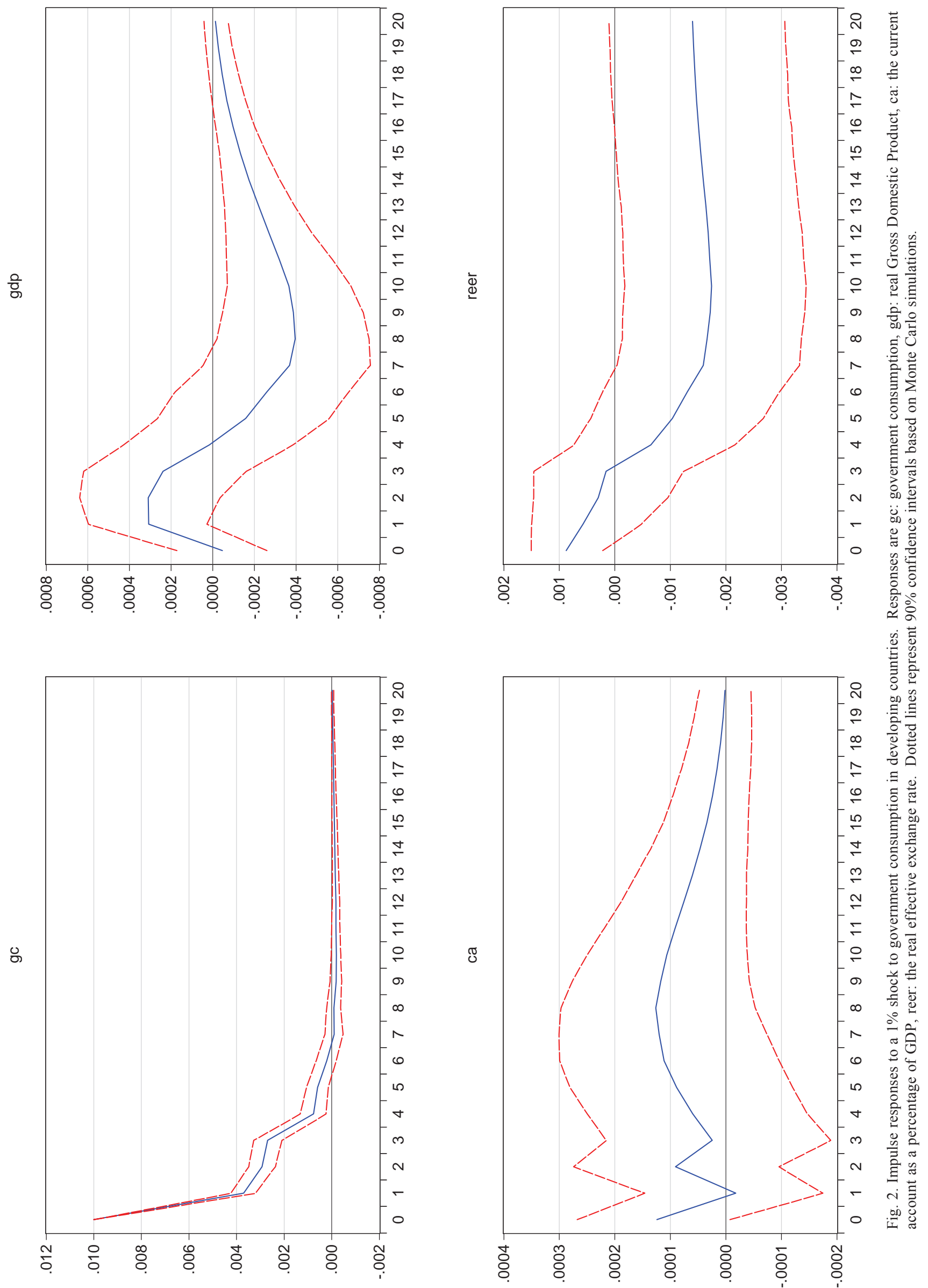


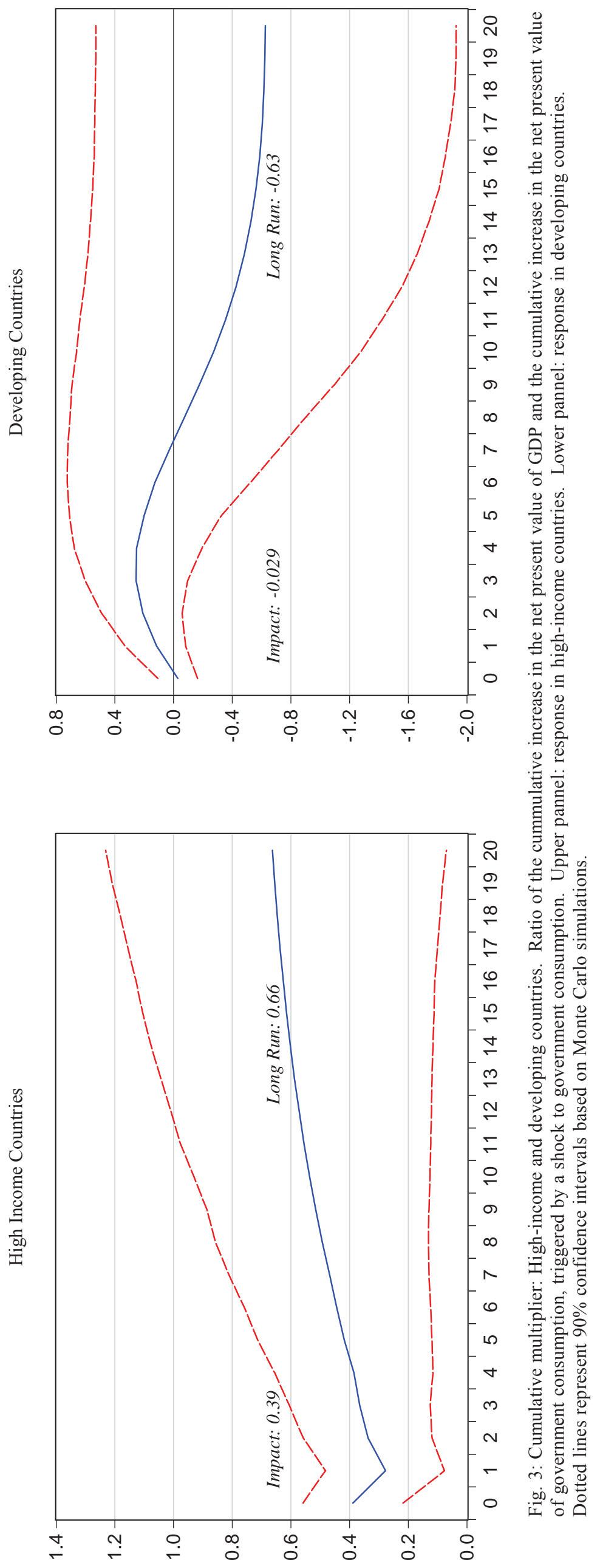




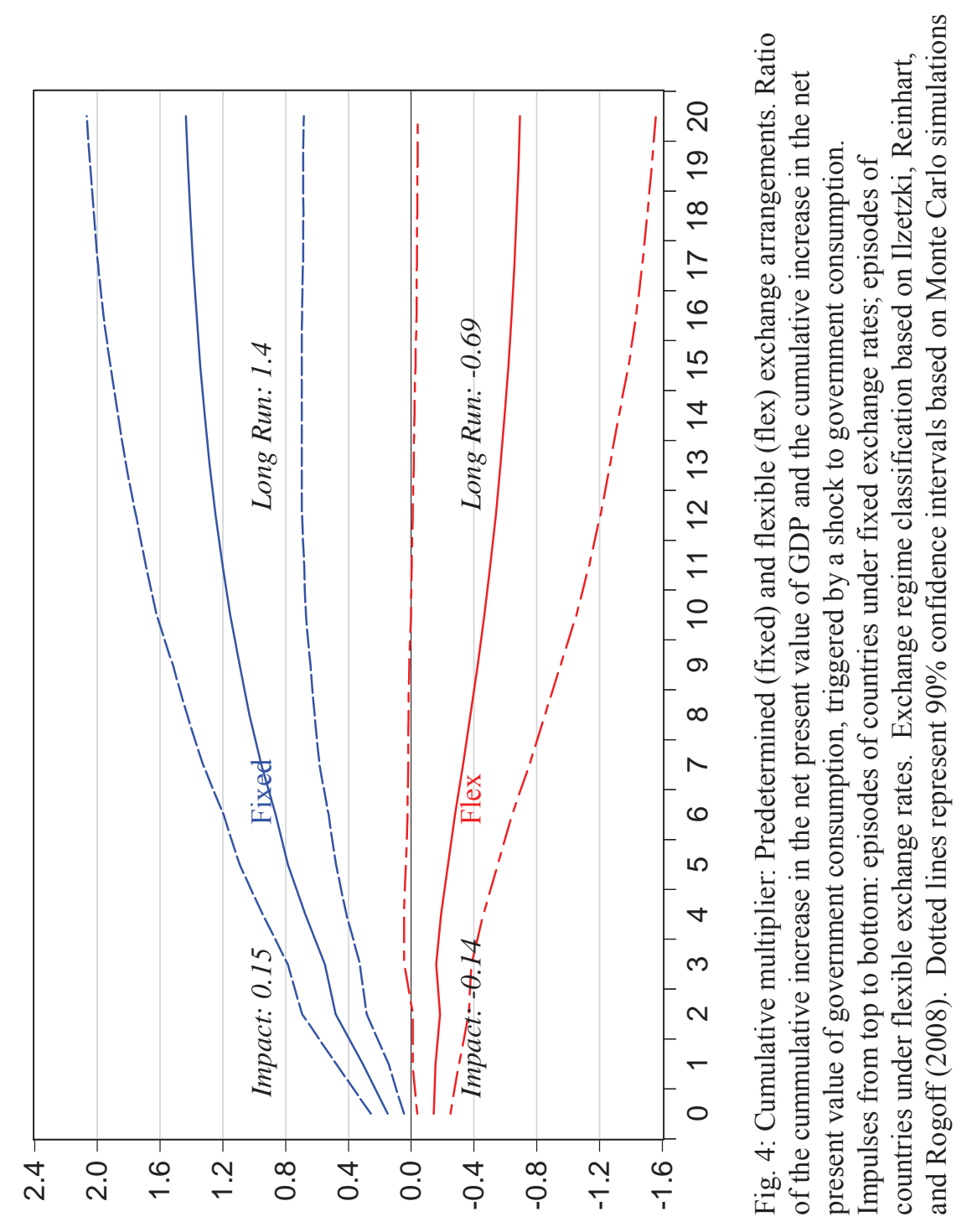




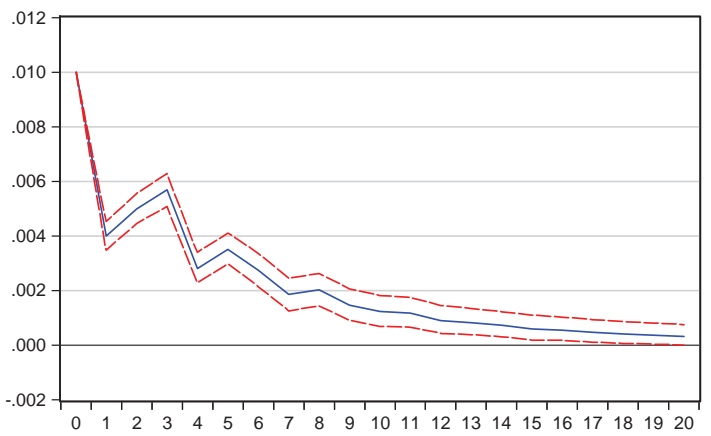

gdp
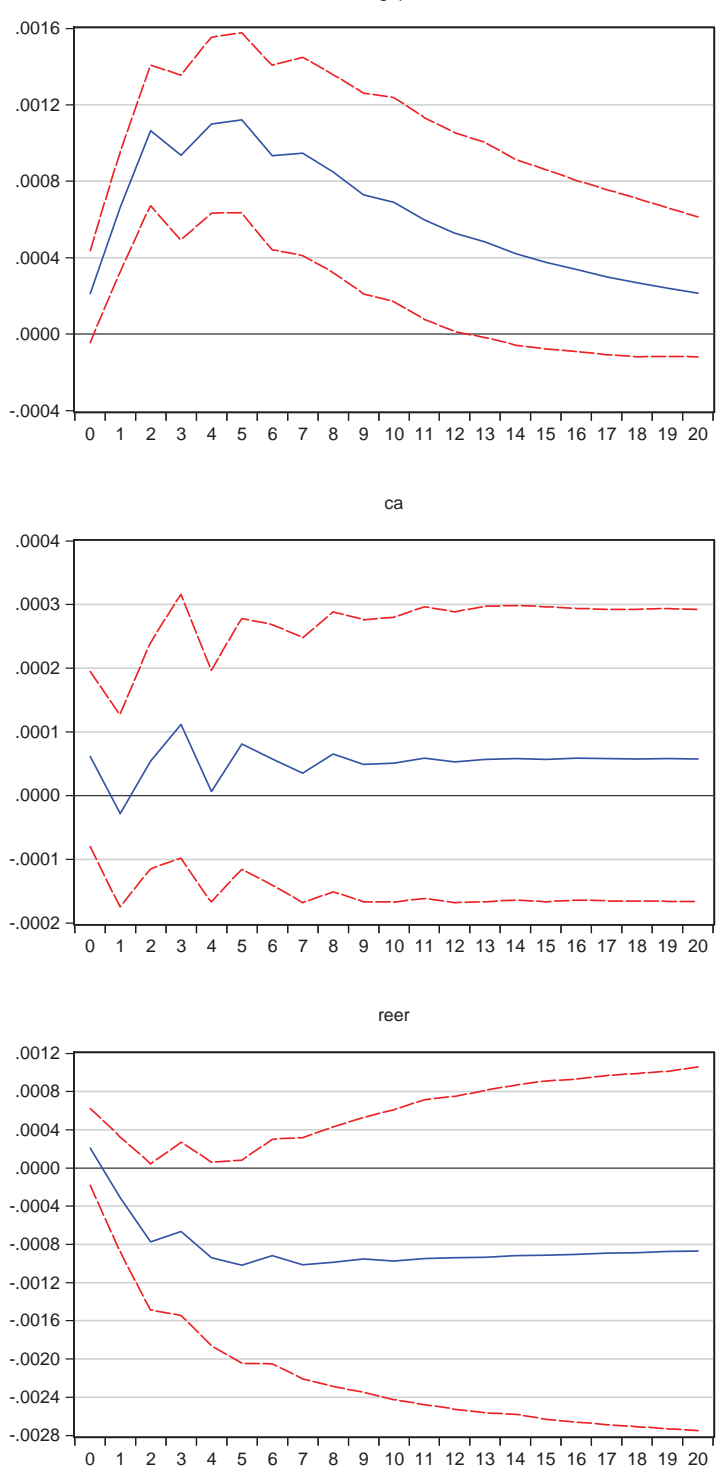

drate

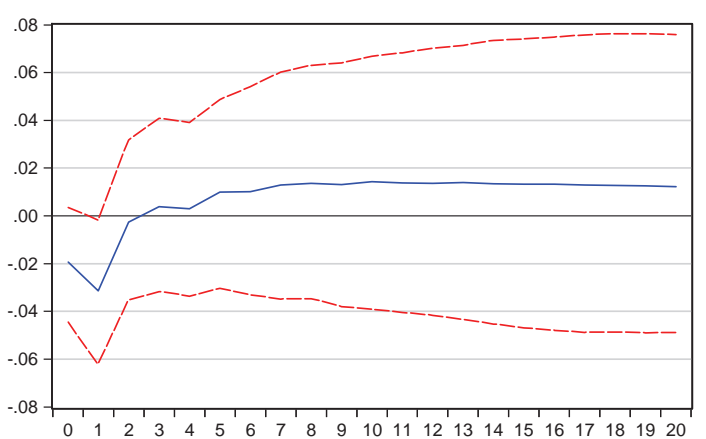

gc

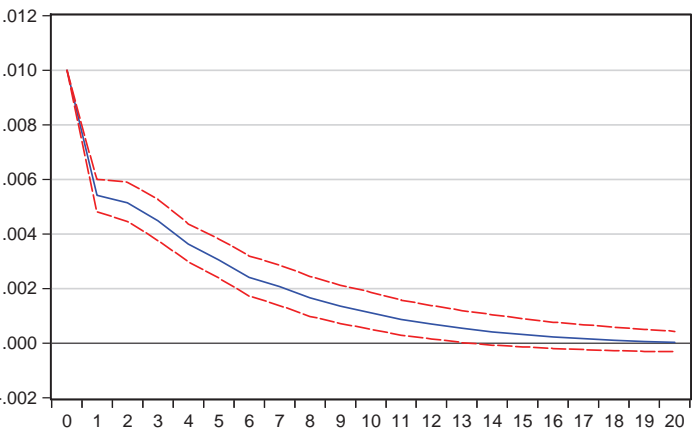

gdp

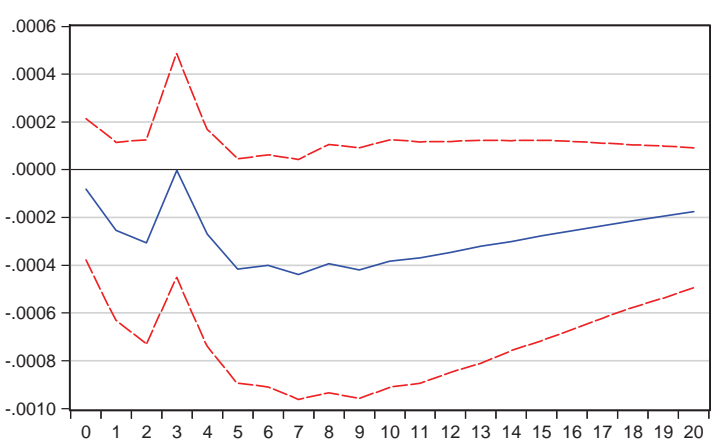

ca
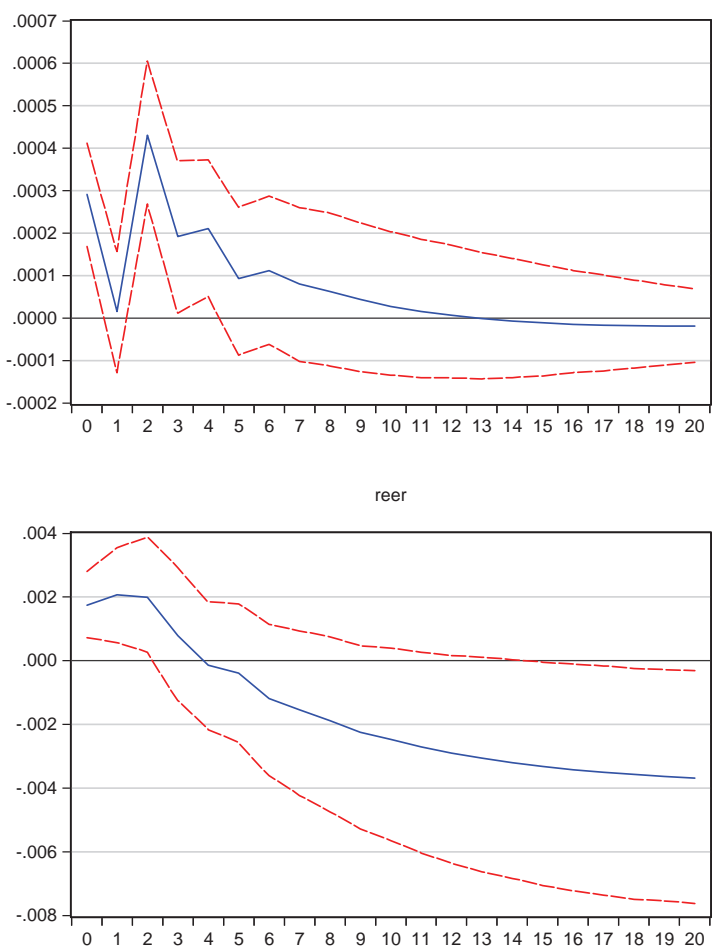

drate

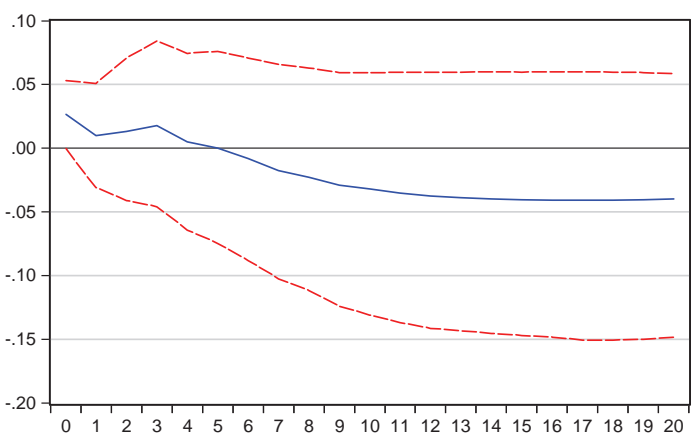

Fig. 5: Impulse responses to a $1 \%$ shock to government consumption in episodes of fixed exchange rates (left panels) and flexible exchange rates (right panels). Impulses from top to bottom: Fig. 5: Impulse responses to a $1 \%$ shock to government consumption in episodes of fixed exchange rates (left panels) and flexible exchange rates (right panels). Imp
Government consumption; Gross Domestic Product; current account as a percentage of GDP; the real effective exchange rate; policy interest rate of the central bank. Government consumption; Gross Domestic Product; current account as a percentage
Dotted lines represent $90 \%$ confidence intervals based on Monte Carlo simulations 

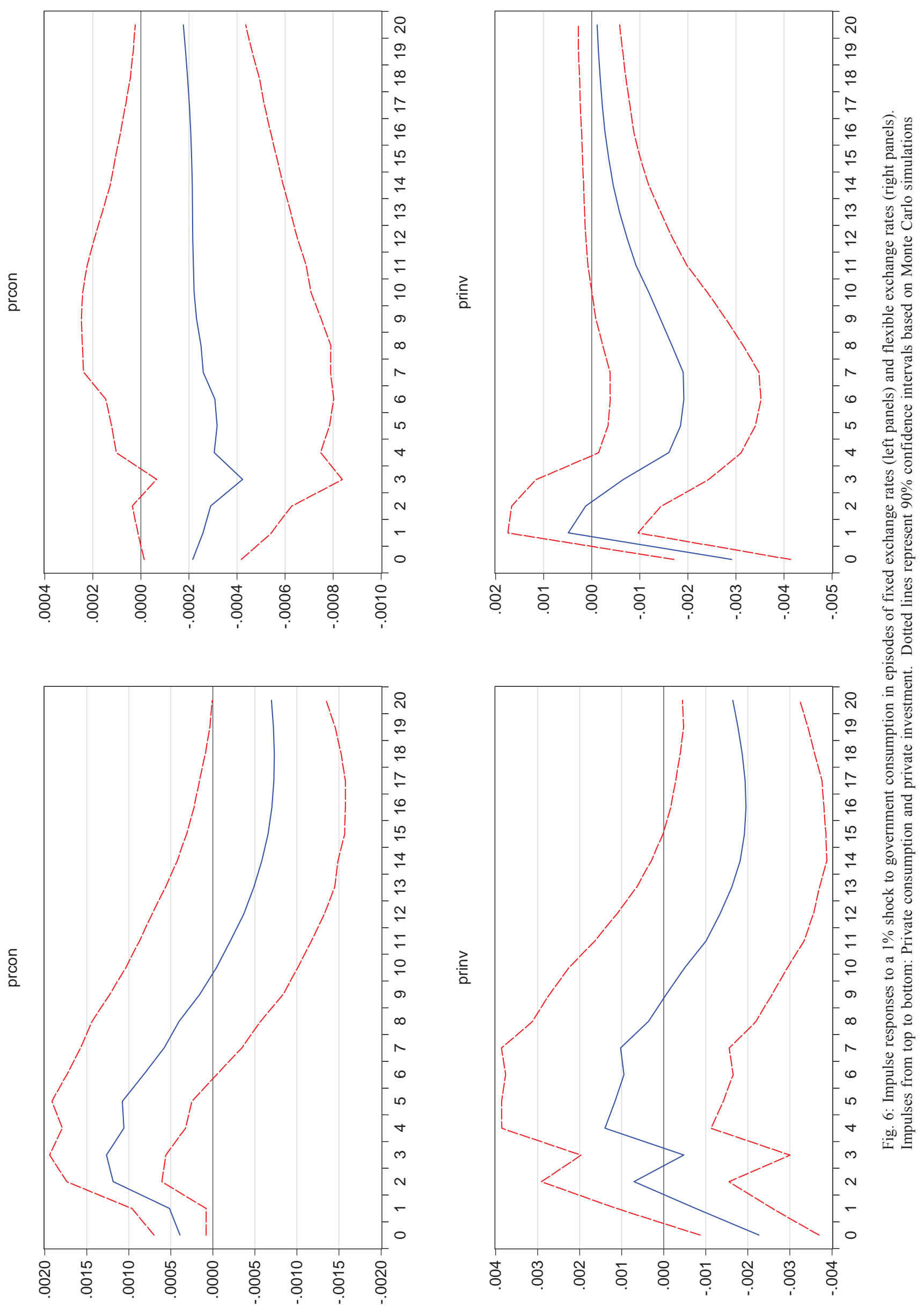


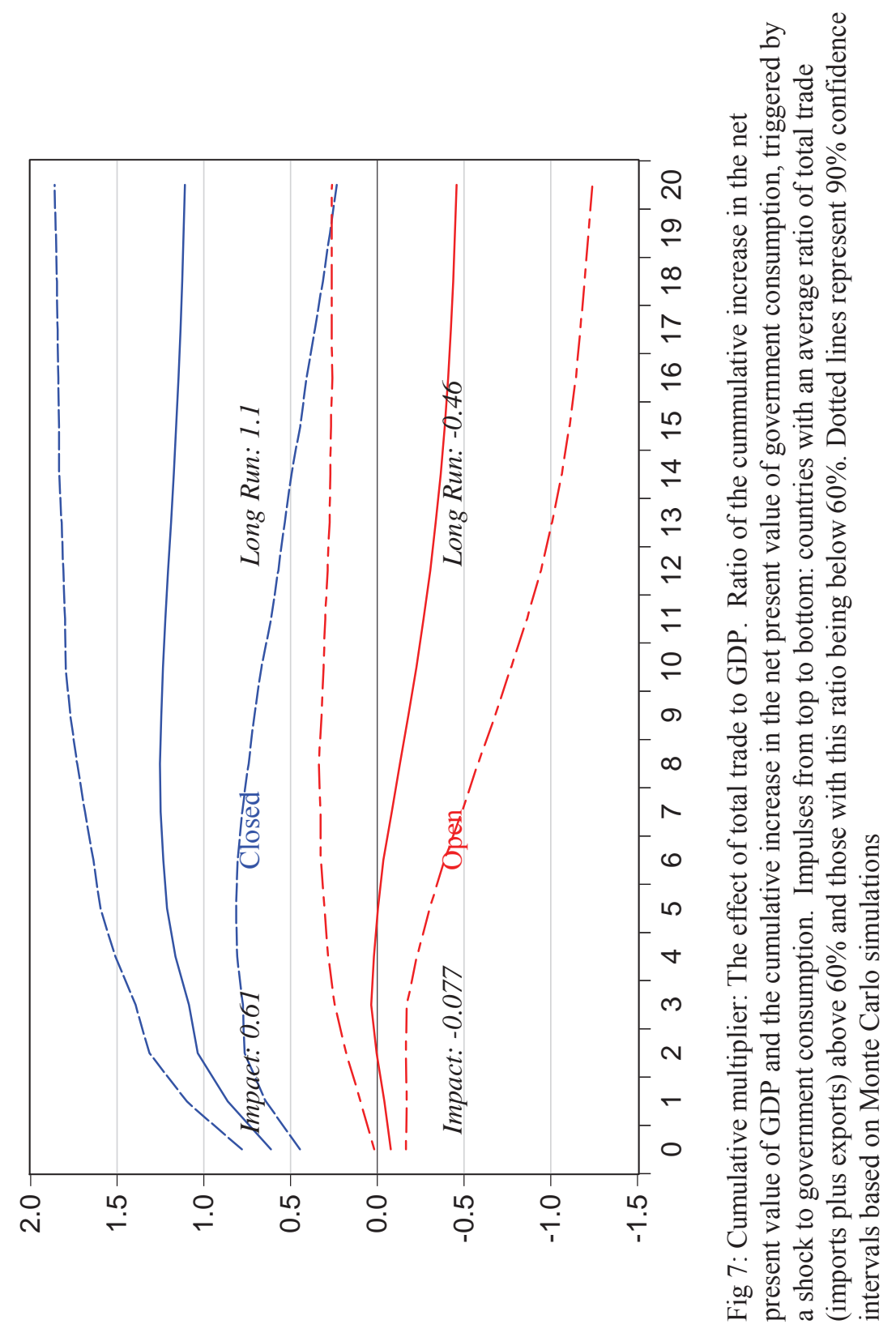




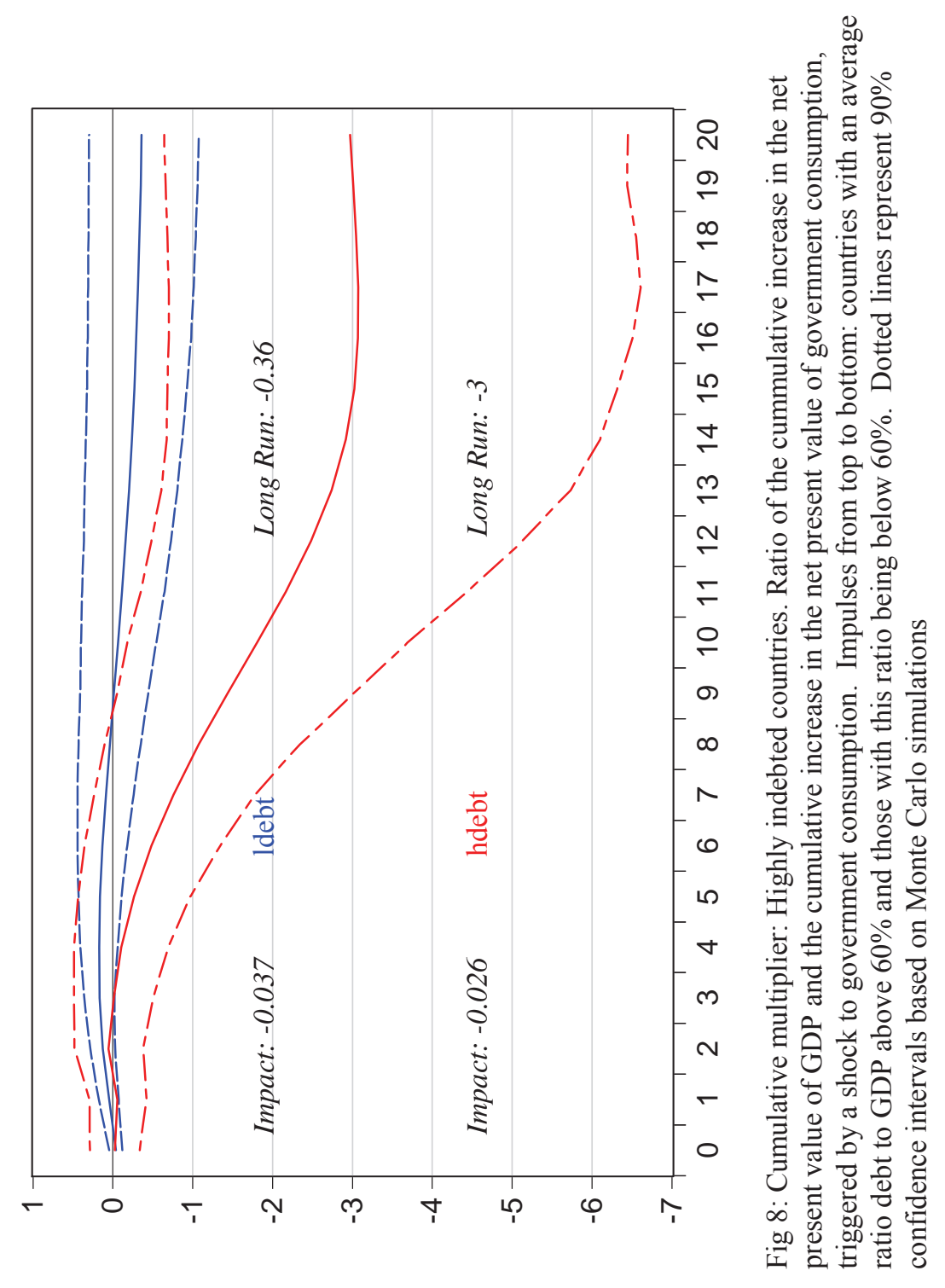




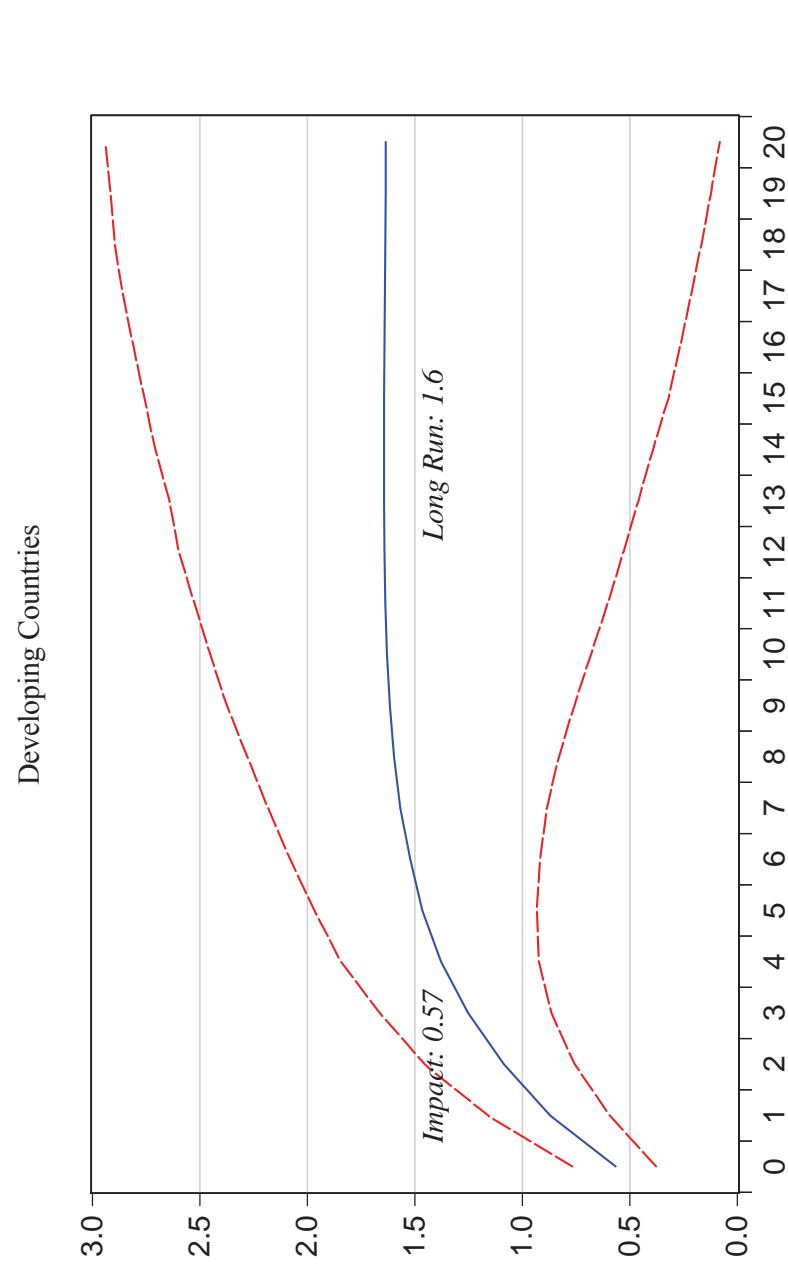

造

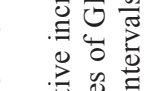

$\infty$ 氜

^ $\quad \overline{0}$

$\circ \quad$

ㄴ)

$\checkmark$ 웜

m 030



인

o

$\infty$.

$\wedge \quad \because$. 흉

( )

o 0

$\checkmark \quad$ 苛方.

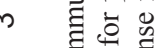

N $\overline{0}$ 응

- 艺宕范

号

के के

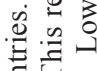

$\dot{\varphi}$

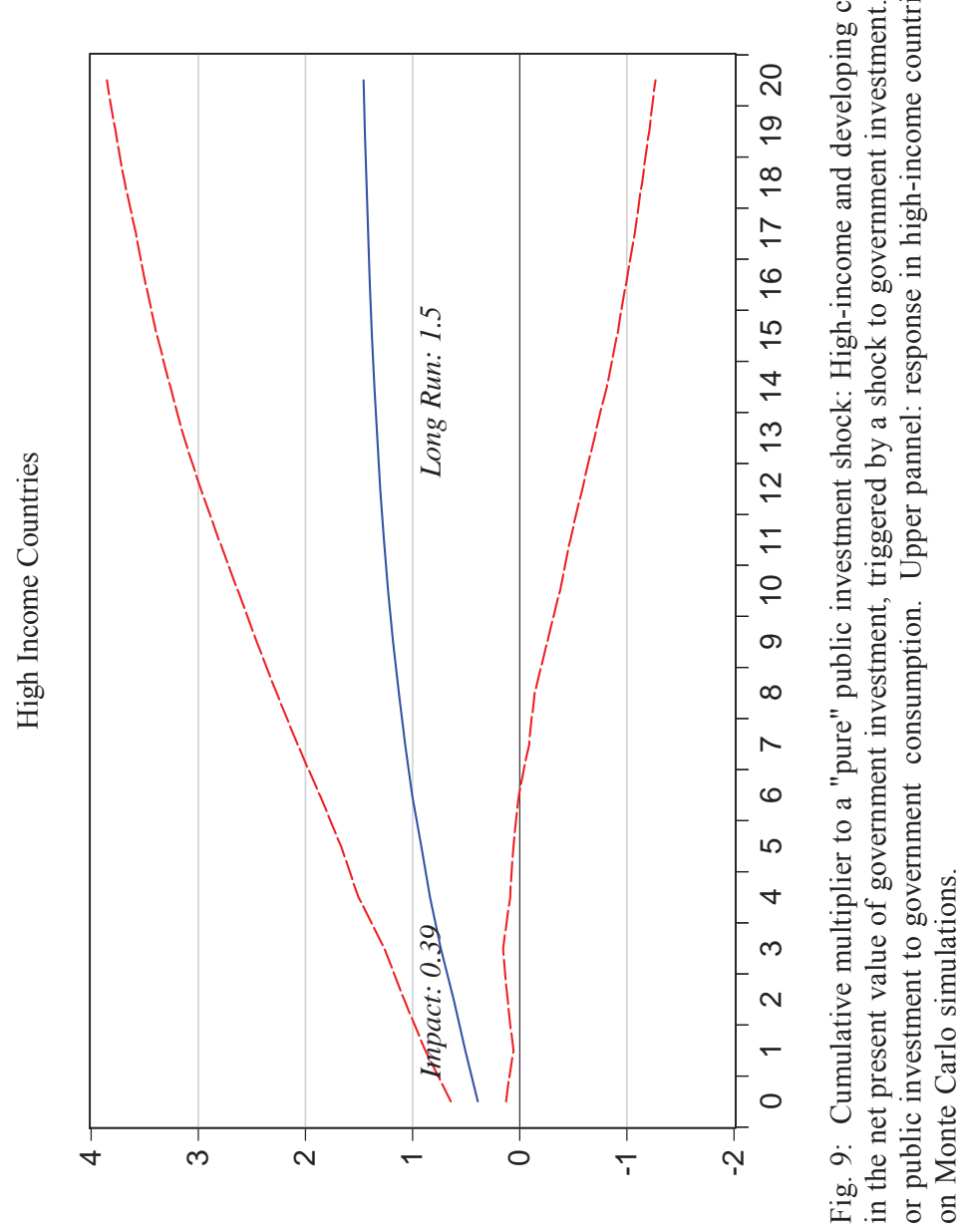

